\title{
Assessment of Reading Proficiency in Urban Education: The Case of Charter Schools in Michigan, United States
}

\author{
Suleiman M. Hamdan', Joseph L. Musial² \\ ${ }^{1}$ American University in Dubai, Dubai, UAE \\ ${ }^{2}$ University of Michigan, Dearborn, Michigan, USA \\ Email: shamdan@aud.edu, musialj@resa.net
}

Received 21 February 2015; accepted 8 March 2015; published 16 March 2015

Copyright (C) 2015 by authors and OALib.

This work is licensed under the Creative Commons Attribution International License (CC BY).

http://creativecommons.org/licenses/by/4.0/

(c) (i) Open Access

\section{Abstract}

The purpose of this qualitative study was to examine the $7^{\text {th }}$ grade reading performance among a random sample of urban public school academies (charter schools) in Wayne County, Michigan, compared with a random sample of traditional urban public schools within the same geographic area. This study was conducted using the fall 2012 Michigan Educational Assessment Program (MEAP) reading test scores, as reported by the Michigan Department of Education. A total of 11 public charter schools were selected and represented $15 \%$ of the total public charters in Wayne County that serviced middle school aged children. The 11 randomly selected Traditional Public Schools used for the comparison represented $10 \%$ of these traditional public schools that were located within a 5-mile radius of the public charter schools. Contingency tables were constructed (type of school vs. reading proficiency) and the data was analyzed using the nonparametric chisquare test for independence. According to the data, the traditional public schools had a higher percentage of grade 7 students who were proficient readers when compared with the public charter schools $(30.7 \%$ vs. $18.6 \%$, respectively). The difference, however, was not statistically significant and the null hypothesis was not rejected. These results suggested that the public charter schools were not outperforming traditional public schools in grade 7 reading proficiency.

\section{Keywords}

Michigan, Reading, Charter Schools, Urban Education

Subject Areas: Demography, Education

\section{Introduction}

Public School Academies (PSA), also referred to as public charter schools, are schools of choice that were

How to cite this paper: Hamdan, S.M. and Musial, J.L. (2015) Assessment of Reading Proficiency in Urban Education: The Case of Charter Schools in Michigan, United States. Open Access Library Journal, 2: e1390.

http://dx.doi.org/10.4236/oalib.1101390 
established with the intent to provide unique educational opportunities for students and communities. Unlike Traditional Public School (TPS) districts in Michigan, public charter schools are authorized by community colleges, universities, intermediate and local school districts. Public charters are also permitted to be managed by for-profit entities. Pursuant to the Michigan Revised School (RSC), also known as Public Act 451 of 1976, a Public School Academy (PSA) is state-supported public school under the state constitution, operating under a charter contract issued by a public authorizing body according to Revised School Coded §380.502 (1) [1].

The first Michigan charter school legislation, Public Act 284, was passed in December 1993. Proponents of the legislation believed that public charters were a necessary reform in public education. Public charter schools serve as a model of accountability and infusion of market competition into public education, and responding to the needs of parents, students and communities [2]. This legislative Act culminated in the opening of the first nine public charter schools in 1994. For example, Aisha Shule and Casa Maria (later named Casa Richard Academy) were among the first Michigan public school charters to be established in Wayne County, Michigan [3]. Since then, there has been a steady increase in the number of Michigan public charter schools despite the closure of some failing academies including the aforementioned Casa Richard Academy which closed its doors in 2014. The Michigan Department of Education reported a total of $N=272$ public charter districts in 2013 with $40 \%$ of them located in Wayne County [4]. Furthermore, the Michigan Association of Public School Academies reported the addition of 34 new public charter schools and the closure of 12 in the fall of 2013, bringing the total number of public charter schools in Michigan to N = 298 [5].

The National Alliance for Public Charter Schools reported that ten public charter schools were terminated and closed down at the end of the 2011-2012 school year, while 33 new public charters opened in the fall of 2012 [6]. In the 2010-2011 school year, Michigan added 20 additional public charters and experienced the closure of three underperforming schools [7]. The proliferation of public charters in Michigan and the continuing closure of some has been a concern for public education advocates. Amber Arellano, the Executive Director of Education Trust-Midwest, asserted that charter school operators should be working on improving struggling schools before opening up new ones [8].

While public charter school management and governance may differ from that of a local district, they must abide by all Michigan legal requirements, state guidelines, and the Michigan School Code [1]. This includes the requirement to employ highly qualified teachers and staff, and to administer all state assessments, such as the Michigan Educational Assessment Program (MEAP) and Michigan Merit Exam (MME) at the appropriate grade levels [1]. The MEAP has been utilized to assess the academic performance of all public school students, including those in public charter schools in grades 3 - 9, while the MME is used to assess students' academic performance in grade 11. The results of the MEAP and the MME tests are included in Michigan's newly created Michigan School Accountability Scorecard [9]. The Scorecards, which replaced the Adequate Yearly Progress (AYP), combined student assessment data with attendance and graduation rates as well as compliance with state and federal laws. The five content areas include mathematics, reading, writing, science and social studies. All Michigan public schools are expected to reach 85\% proficiency in all content areas by the 2021-2022 school year. The MEAP and MME results report students' proficiency levels in each of the tested content areas. Students' performance is rated at one of the following four levels: advanced (level I), proficient (level II), partially proficient (level II) and not proficient (level IV). The goal is to have all students perform at or above the proficient level.

The purpose of this study was to examine the performance of students in both public charters and traditional public schools in Wayne County on the $7^{\text {th }}$ grade MEAP assessment in reading. In order to conduct the study, the following hypothesis was generated:

$H_{o}$ (Null): Among grade 7 Wayne County students, there is no relationship between the type of public school and reading proficiency on the $7^{\text {th }}$ grade MEAP reading assessment.

$H_{A}$ (Alternative): Among grade 7 Wayne County students, there is a relationship between the type of public school and reading proficiency on the $7^{\text {th }}$ grade MEAP reading assessment.

This information can be useful for school teachers, administrators and parents who are concerned with educational reform and school choice. School administrators and teachers-more specifically those in urban areas-can use the results of this study to gain a greater understanding of the level of public charter schools performance and to examine challenges and opportunities that will improve achievement and ensure success for all students. In addition, the findings will be critical for the educational community in seeking a unified and coherent approach to address the needs of all students separate from the competitive and adversarial relation-ships 
between the proponents of public charter schools and of traditional public schools.

Furthermore, this study is important in other respects. The educational community has been continually reminded that legislators and choice advocates who gave impetus to the creation of public school academies promoted them as a unique addition or an alternative to the public school system. Thus, this study will provide a critical and an analytical perspective for both opponents and proponents of the public charter movement to examine the extent of adherence to the public charters' unique mission and to explore collective measures based on sound pedagogical theory and best practices.

Although the research is limited to $7^{\text {th }}$ grade reading performance, the findings will call attention to further study of potential gaps in other subject areas and grade levels within urban schools. Additionally, the study could be replicated to examine similar variables in non-urban settings to discover any potential gaps and disparities. The demographic realities in Wayne County bring another important factor that cannot be overlooked. Wayne County is the largest county in Michigan with the largest concentration of public charters in the state totaling $40 \%$ of all Michigan charters. It is also a region with a higher concentration of poor and minority populations than any other county in Michigan. The U.S. Census Bureau reported that $22.7 \%$ of the county's population lives below the poverty line, while $44.3 \%$ are African-American [10]. The awareness of the performance trends within high minority communities is critical for educators and communities as they set out to plan improvements and implement curricular and instructional measures to meet the needs of public charter school students.

\section{Background}

The charter school educational reform incorporated the principles of market economy in promoting competition, deregulation, and accountability. These principles have been based on the premise that market economy principles will contribute to innovation and reform within the public school system [11]. Much of the support for this type of reform has also been premised on the theory that public charters will empower communities to develop and support their own schools [12]. The early proponents of charter public schools argued that these new models of schools would provide an opportunity for improved student achievement through unique programs, innovative teaching methods, enhanced accountability and autonomy, parental choice and effective utilization of resources [13]. The sustained efforts of charter school reformists were reinforced by the No Child Left Behind Act (NCLB) of 2001, which promoted charter schools as a public school alternative to and catalyst for the improvement of failing schools [14].

For the most part, Michigan's public charter schools tend to attract minority students within segregated demographic patterns. A two-year study showed that Michigan's public charter schools enrolled a greater number of African American students and had more students who qualified for free or reduced lunch programs [15]. The Center for Educational Reform found that the majority of students who enroll in Michigan's public school charters share several characteristics that include at-risk backgrounds, low socio-economic status and belonging to a minority group [16]. For example, Detroit's public charter schools serve student populations that are almost $100 \%$ at-risk, low income and minority. Studies suggested that public charter schools are most likely to be comprised of a significant portion of the market share of public education within big cities with large AfricanAmerican populations, such as New York, Detroit, St. Louis, Washington DC and New Orleans [17]. States with higher numbers of African-American and Hispanic students also have greater numbers of public charter schools [18]. In fact, a large number of public charter schools are located in hyper-segregated cities such as Detroit, where the majority population is African-American, and student enrollment that follows a predominantly segregated pattern due to inadequate accessibility to transportation outside the community [19]. Indeed, with limited transportation opportunities, students who are confined to segregated communities have limited mobility to attend a school beyond their immediate geographic area.

Public charter school proponents argue that such high concentrations of minority enrollment within public charters is attributed to the high demand for educational choice and alternatives among minorities, whom they say have been traditionally underserved by the traditional school system [16]. A study conducted in 2010 by researchers at the University of Colorado-Boulder and Western Michigan University found that most public charter school were divided between either very segregated high-income schools, or very segregated low-income schools. The study also found that these public charters tended to enroll smaller numbers of special education students and English Language Learners [20]. 
In addition to attracting primarily minority student populations, public charter schools also attract largely inexperienced teachers. According to data from Michigan's Center for Educational Performance and Information (CEPI) for the 2011-2012 school year, 31\% of teachers in Michigan's public charter schools had less than one year of teaching experience, while $4 \%$ had over 11 years of teaching experience. In comparison, $3 \%$ percent of traditional public school teachers had less than one year of teaching experience, while 25 percent had more than 11 years of teaching experience [21].

Why do some parents choose public charter schools? There are various reasons including safety, small class size, purported uniqueness, and perception of unmet needs within the traditional public school system. Parents who enroll their children in public charter schools believe that charters would be able to accommodate the needs of their children within a system where they have greater access to teachers and administrators than in traditional public schools [18]. Others enroll their children due to the potential benefit of safety and smaller class size [22]. In addition, there are some parents who believe that public charters provide curriculum content that is geared toward the individual needs of students to keep them more challenged [8].

\section{Meeting the Expectations}

While proponents continue to believe in the viability of the public charter school system, the performance results of public charters have had mixed results. Since the inception of public charter schools nearly two decades ago, it can be argued that the research has overemphasized the comparisons with local district performance rather than with the state-wide performance levels. An analysis by the Michigan Association of Public School Academies that used the 2011-2012 MEAP reading and math results for grades 3 - 8, found that African-American students in public charter schools scored higher than African-American students in traditional public schools within the same host districts [23].

The analysis also found that the largest gaps were in the MEAP reading scores. For example, $43.6 \%$ of African-American students in public charters were proficient in reading, compared to $34.3 \%$ of African-American students in traditional public schools. The performance gap in the MEAP reading scores were also large in Detroit, where $42.5 \%$ of public charter schools students were proficient, compared to $35.5 \%$ proficient among their counterparts in the Detroit Public Schools. In contrast, a similar analysis conducted by the Detroit News found that the majority of high school charters in Detroit underperformed their counterparts in the traditional public schools in all subject areas except social studies [24].

However, a recent study of MEAP and MME results found that while public charter schools test results were at or below statewide averages in Michigan, they had followed a similar pattern of achievement as that of traditional public schools, for both the less-advantaged and better-off students [25]. On the other hand, other researchers pointed out the positive impact that public charter schools had on the achievement of low income and minority students. A study commissioned by the Boston Foundation highlighted the influence of well-run charters in meeting the needs of inner-city children. The Boston study relied on a comparison of the test scores of students who were actually admitted to public charters through the lottery system to the test scores of students who were entered into the lottery but were not selected. According to the results of the study, students who had won the admission lottery and enrolled in the public charter schools made greater gains in mathematics and English scores than students who had lost the admission lottery and remained in the traditional public school [26]. A more recent study by the Boston Foundation also found that public charter school students outperformed their peers in traditional public schools on standardized tests and 4-year college enrollment rates [27].

According to a national study which involved public school charters in 16 states, the Center for Research on Educational Outcomes (CREDO) found that $46 \%$ of public charter schools showed no significant difference in achievement when compared to their counterparts in the traditional public schools, while $37 \%$ of public charter schools performed below the achievement level of traditional public school counterparts, with $17 \%$ of public charter schools reporting academic gains that were significantly better than traditional public schools [28]. Several research studies found that public charter school students demonstrated achievement levels that were similar or lower than the achievement of traditional public school students [29]. A recent CREDO study released in 2013 showed that slightly more than one-half of Detroit's public charters were not significantly different in their student performance when compared to their traditional public school counterparts [30]. The same study found that Michigan's public charter schools showed modest improvements since 2009, although some of the improvements were attributed, in part, to the closure of poor performing public charters and the declining per- 
formance of traditional public schools [30].

\section{Methods}

This qualitative study consisted of using publicly available data results from the $7^{\text {th }}$ grade reading component of the Michigan Educational Assessment Program (MEAP) for the fall 2012 test cycle (www.michigan.gov/meap). The MEAP is a criterion-referenced assessment which is comprised of five content areas: reading, writing, math, science and social studies for grades $3-8$, and $9^{\text {th }}$ grade social studies. While reading and math were administered in all grades, the other subjects varied by grade. The Michigan Department of Education required all public school to administer the MEAP and insure 95\% student participation rate. Specifically, this secondary data analysis used reading proficiency results from a random selection of Wayne County, Michigan traditional public schools and public charter schools. The publicly available data sets were downloaded from the Michigan Department of Education's web site and were then abstracted. There were a total of $n=11$ (15\%) public charter schools that educated grade 7 students, and $n=11$ traditional public schools $(10 \%)$ that were located within a 5-mile radius of the public charter schools' zip code, and also provided education for grade 7 students. The identification of traditional public schools was conducted through a web-based search on www.greatschools.org, where the distance parameter was set at a 5-mile radius from the public charter school zip code [31]. The public charter schools were selected from the 2011-2012 Wayne County School Directory [32]. The random samples were generated using the random number generator available in SPSS [33]. The sampling plan excluded magnet schools and any school with a special population, such as strict discipline academies, residential treatment centers and youth detention facilities. Additionally, the sampling of traditional public schools excluded all schools that have been transformed into charter academies, and those that were transferred to the jurisdiction of the Education Achievement Authority (EAA) and private management companies. Table 1 includes the charter public schools sample and the associated reading proficiency levels on the grade 7 MEAP (see Table 1). The sample of traditional of public schools is represented within Table 2 (see Table 2).

In order to carry out the analysis, a $2 \times 2$ contingency table was constructed in SPSS and consisted of the type of school (TPS/PSA) compared to grade 7 MEAP reading proficiency (yes/no). The reading proficient category included students who had performed at the advanced level (level I) and the proficient level (level II). The non-proficient category included students who performed at the partially proficient level (level III) and the not proficient level (level IV). The nonparametric chi-square test for independence was performed. Chi-square is well suited for analyzing contingency tables that employ nominal variables and is rather flexible because

\begin{tabular}{cccc}
\hline \multicolumn{3}{c}{ Table 1. Performance summary on $7^{\text {th }}$ grade reading MEAP of selected charters (Fall 2012). } \\
\hline $\begin{array}{c}\text { Public School Academy } \\
\text { (PSA) }\end{array}$ & Total tested students & $\begin{array}{c}\text { Percent (\%) proficient } \\
2012 \text { (Levels 1 \& 2) }\end{array}$ & $\begin{array}{c}\text { Percent (\%) } \\
\text { non-proficient 2012 } \\
\text { (Levels 3 \& 4) }\end{array}$ \\
\hline PSA-A & 81 & $93.8 \%$ & $6.2 \%$ \\
PSA-B & 192 & $24 \%$ & $76 \%$ \\
PSA-C & 248 & $35.5 \%$ & $64.5 \%$ \\
PSA-D & 43 & $81.4 \%$ & $18.6 \%$ \\
PSA-E & 100 & $25 \%$ & $75 \%$ \\
PSA-F & 47 & $23.4 \%$ & $76.6 \%$ \\
PSA-G & 130 & $35.4 \%$ & $64.6 \%$ \\
PSA-H & 115 & $56.5 \%$ & $43.5 \%$ \\
PSA-I & 140 & $47.1 \%$ & $52.9 \%$ \\
PSA-J & 79 & $38 \%$ & $62 \%$ \\
PSA-K & 41 & $65.9 \%$ & $34.1 \%$ \\
\hline
\end{tabular}

Note. Source: Michigan department of education (2013). 
Table 2. Performance summary on $7^{\text {th }}$ grade reading MEAP of selected traditional public schools (Fall 2012).

\begin{tabular}{cccc}
\hline $\begin{array}{c}\text { Traditional Public } \\
\text { School (TPS) }\end{array}$ & Total tested students & $\begin{array}{c}\text { Percent (\%) proficient } \\
2012\end{array}$ & $\begin{array}{c}\text { Percent (\%) } \\
\text { non-proficient 2012 }\end{array}$ \\
\hline TPS-A & 65 & $27.7 \%$ & $72.3 \%$ \\
TPS-B & 294 & $70.4 \%$ & $29.6 \%$ \\
TPS-C & 155 & $48.4 \%$ & $51.6 \%$ \\
TPS-D & 38 & $28.9 \%$ & $71.1 \%$ \\
TPS-E & 37 & $24.3 \%$ & $75.7 \%$ \\
TPS-F & 235 & $48.5 \%$ & $51.5 \%$ \\
TPS-G & 355 & $60.3 \%$ & $39.7 \%$ \\
TPS-H & 249 & $67.5 \%$ & $32.5 \%$ \\
TPS-I & 197 & $58.9 \%$ & $41.1 \%$ \\
TPS-J & 28 & $57.1 \%$ & $42.9 \%$ \\
TPS-K & 252 & $61.5 \%$ & $38.5 \%$ \\
\hline
\end{tabular}

Note. Source: Michigan department of education (2013).

chi-square is distribution-free [34]. The significance level was set at an alpha level of 0.05 with 1 degree of freedom.

\section{Results and Analysis}

According to the data, traditional public schools had a higher reading proficiency rate than the public charter schools (30.7\% vs. $18.6 \%)$, however, the results were not statistically significant, Pearson $X^{2}(1, N=3121)=$ 1.87, $p=0.172$. Therefore, we failed to reject the null hypothesis (see Table $3 \&$ Table 4). The results also suggest that the student performance on the grade 7 MEAP reading section for the random sample of Wayne County public charter school students were similar to the performance of the random sample of traditional public school students.

\section{Conclusion}

This study found no significant difference in grade 7 reading proficiency when public charter schools were compared to traditional public schools. These findings run contrary to various multi-media marketing campaigns that are commonplace in Wayne County. This would include those public charter schools that purport to be "college ready", "innovative", and "unique" to name a few. There are several limitations associated with this study. The limitations include a small sampling plan, the restriction to only one content area, as well as the lack of experimental control, i.e., the inability to randomize students to the type of public school setting. In addition, one is refrained from making statements of generalizability, while taking into account that public charter schools draw upon enrollment beyond the geographic boundaries of the residential public school district. Future researchers should consider employing a larger sampling plan that utilizes multiple settings, including rural areas as well as various socio-economic demographics. Nevertheless, publicly available data permits one to test various research hypotheses in a rather efficient and cost-effective manner. The authors had assumed a gap in proficiency based on their close working relationships with various Wayne County public charter schools, as well as an intimate knowledge of their curriculum and their MEAP proficiency trends. Significant research studies found public charter schools to underperform when compared to their traditional public school counterparts, or at best, to perform within the same performance level [35].

In addition, the results of this study provide an opportunity for charter school advocates to examine the conditions that have hampered their ability to translate the charter schools' uniqueness and innovation into better student results. It remains unclear why the public charter schools academic outcomes were not significantly better 
Table 3. School type * grade 7 fall 2012 reading status cross-tabulation.

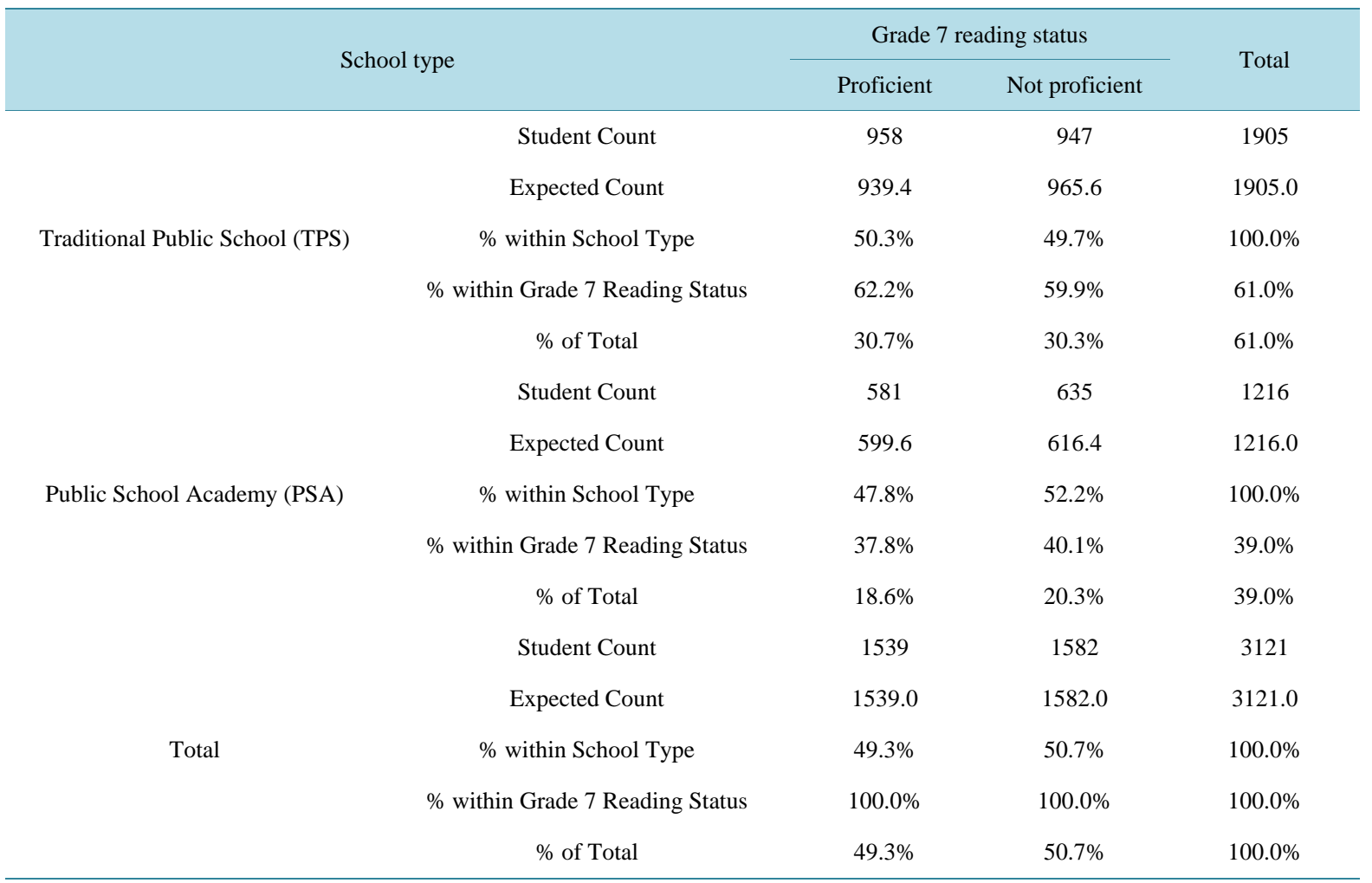

Table 4. Chi-square test.

\begin{tabular}{|c|c|c|c|c|c|}
\hline & Value & $d f$ & $\begin{array}{l}\text { Asymp. Sig. } \\
\text { (2-sided) }\end{array}$ & $\begin{array}{c}\text { Exact Sig. } \\
\text { (2-sided) }\end{array}$ & $\begin{array}{l}\text { Exact Sig. } \\
\text { (1-sided) }\end{array}$ \\
\hline Pearson Chi-Square & $1.869^{\mathrm{a}}$ & 1 & 0.172 & & \\
\hline Continuity Correction ${ }^{\mathrm{b}}$ & 1.770 & 1 & 0.183 & & \\
\hline Likelihood Ratio & 1.870 & 1 & 0.171 & & \\
\hline Fisher's Exact Test & & & & 0.175 & 0.092 \\
\hline Linear-by-Linear Association & 1.869 & 1 & 0.172 & & \\
\hline $\mathrm{N}$ of Valid Cases & 3121 & & & & \\
\hline
\end{tabular}

Notes: ${ }^{\mathrm{a}} 0$ cells $(0.0 \%)$ have expected count less than 5 . The minimum expected count is $599.62 ;{ }^{\mathrm{b}}$ Computed only for a $2 \times 2$ table.

than their traditional public school counterparts, especially when both were located in the same geographic location.

A few years before public charter schools were catapulted into the arena of school reform in Michigan, Lee Shulman of Stanford University argued the case for pedagogical reform. In his 1987 essay in the Harvard Educational Review, he discussed what he thought to be a sound pedagogical foundation for educational reform. He argued that reform must be based on deep knowledge, pedagogical reasoning, transformation, and reflection [36]. The efficacy of pedagogical reform has been reinforced by recent research on high performing public charter schools. In a study of five high performing public charter schools, researchers found that all of the schools in their study shared several successful practices and strategies that included a primary focus on the individual student and teacher [37]. At the heart of these strategies were various reading programs implemented during the course of the school day, attention to individual needs, encouragement of collegial reflection, emphasis on teaching higher order thinking skills, emphasis on outcomes, recruitment of high quality teachers, pedagogical 
freedom, focus on maximizing instructional time, teacher training, and mentoring. Other studies showed that successful urban schools tend to share a core of characteristics that include: a strong and pervasive mission, ethical standards that align with the mission, focus on staff quality, best practices based on deep differentiation, engagement with all stakeholders, and personalized relationships [38]. Perhaps, it is time to revisit these ideas!

\section{Acknowledgements}

The authors would like to acknowledge Dr. Kenneth Garner for his thoughtful editing and data quality assurance assistance and Dr. Rosalyn Shahid for her valuable review, critique and recommendations.

\section{References}

[1] Michigan Department of Education (2012) Michigan Charter Schools: Questions and Answers. http://www.michigan.gov/documents/PSAQA_54517_7.pdf

[2] Goenner, J. and Irwin, A. (2001) Charter Public Schools: New Options for Michigan Families. Michigan Family Review, 6, 13-23. http://hdl.handle.net/ 2027/spo.4919087.0006.102

[3] Center for Charter Schools (2009) 15 Years of Transforming Public Education. http://www.cmucso.org/modules.php?name=Documents\&op=viewlive\&sp_id=251

[4] Michigan Department of Education (2013) Directories and Lists. http://www.michigan.gov/documents/mde/PSAs 297270 7.pdf

[5] Michigan Association of Public School Academies (MAPSA) (2013) Media Release: September 3, 2013—School Year Begins with 298 Charter Schools in Michigan. http://charterschools.org/press-room/1365

[6] National Alliance for Public Charter Schools (2013) Back to School Tallies: Estimated Number of Public Charter Schools \& Students, 2011-2012.

http://www.publiccharters.org/wp-content/uploads/2014/01/NAPCS-2012-13-New-and-Closed-Charter-Schools_20130 114T161322.pdf

[7] National Alliance for Public Charter Schools (2011) Back to School Tallies: Estimated Number of Public Charter Schools \& Students, 2010-2011.

http://www.publiccharters.org/wp-content/uploads/2014/01/NAPCS-2011-12-New-and-Closed-Charter-Schools_20111 206T125251.pdf

[8] Higgins, L. (2012) Michigan Has More Charter Schools Than Ever, But What's the Smartest Choice. Detroit Free Press, Detroit.

http://archive.freep.com/article/20120909/NEWS06/309090157/Michigan-has-more-charter-schools-than-ever-but-wha t-s-the-smartest-choice-

[9] Michigan Department of Education (2013) Fall 2012 MEAP One Year Public Results. [Data File]. http://www.michigan.gov/mde/0,1607,7-140-22709_31168_31530---,00.html

[10] U.S. Census Bureau (2011) State and County Quick Facts. http://quickfacts.census.gov/qfd/states/00000.html

[11] Mickelson, R.A., Bottia, M. and Southworth, S. (2008) School Choice and Segregation by Race, Class, and Achievement. http://nepc.colorado.edu/publication/school-choice-and-segregation-race-class-and-achievement

[12] Johnson, S.P. (2004) Charter Schools: A Descriptive Study of Empowerment within the Operation of Charter Schools. Dissertation.com, Boca Raton.

[13] Bulkley, K. and Fisler, J. (2002) A Decade of Charter Schools: From Theory to Practice. CPRE Research Report Series RB-35, Consortium for Policy Research in Education, Philadelphia.

[14] U.S. Department of Education (2006) Stronger Accountability: Questions and Answers on No Child Left Behind. U.S. Department of Education, Washington DC.

[15] Craig, S. (2009) A Comparative Analysis of Factors Associated with Academic Outcomes among Michigan Public School Academies, Public Schools, and Host Districts. ProQuest Digital Dissertations, AAT 3350299.

[16] Center for Educational Reform (2010) Annual Survey of America’s Charter Schools. https://www.edreform.com/wp-content/uploads/2011/09/CER Charter Survey 2010.pdf

[17] Frankenberg, E., Siegel-Hawley, G. and Wang, J. (2010) Choice without Equity: Charter School Segregation and the Need for Civil Rights Standards. The Civil, Los Angeles.

[18] Rights Project/Proyecto Derechos Civiles at UCLA. http://civilrightsproject.ucla.edu/research/k-12-education/integration-and-diversity/choice-without-equity-2009-report/f rankenberg-choices-without-equity-2010.pdf 
[19] Kayes, M. and Maranto, R. (2006) A Guide to Charter Schools: Research and Practical Advise for Educators. Rowman \& Littlefield Publishers, Lanham.

[20] Orfield, G. (2010) Foreword. In Choice without Equity: Charter School Segregation and the Need for Civil Rights Standards. The Civil Rights Project/Proyecto Derechos Civiles at UCLA. www.civilrightsproject.ucla.edu

[21] Miron, G., Urschel, J.L., Mathis, W.J. and Tornquist, E. (2010) Schools without Diversity: Education Management Organizations, Charter Schools and the Demographic Stratification of the American School System. Education and the Public Interest Center \& Education Policy Research Unit. http://nepc.colorado.edu/publication/schools-without-diversity

[22] Chambers, J. (2013) Michigan Charter School Teachers Often Less Experienced. Detroit News. http://charterpulse.com/2013/09/20/amid-growth-of-michigan-charter-schools-teachers-often-less-experienced/

[23] Turnbaugh-Lockwood, A. (2004) The Charter Schools Decade. Scarecrow, Education. Rowman \& Littlefield Publishing Group, Inc., Lanham.

[24] Michigan Association of Public School Academies (MAPSA) (2012) Media Release: 6 June 2012. Closing the Achievement Gap: MEAP Results Show That African American Students Perform Better in Charter Schools in Michigan. http://charterschools.org/press-room/1227-june-6-2012-

[25] Detroit Charter High Schools Underperform Public Counterparts, Analysis Shows. The Huffington Post. http://www.huffingtonpost.com/2011/07/08/detroit-charter-high-schools-underperform_n_893327.html

[26] Derringer, N. (2012) Charter Schools: Different Road, but Still Bumpy. Bridge Magazine. http://bridgemi.com/2012/03/charter-schools-different-road-but-still-bumpy/

[27] Peirce, N. (2010) Charter Schools Proving Their Mettle. http://www.thefreelibrary.com/Charter+schools+proving+their+mettle.-a0227363405

[28] Boston Foundation (2013) M.I.T. Report Finds Boston Charter School Students Outperform Peers on Tests, 4-Year College Enrollment. http://www.tbf.org/news-and-events/news/2013/may/mit-report-on-charters

[29] Center for Research on Educational Outcomes (CREDO) (2009) Multiple Choice: Charter School Performance in 16 States. http://credo.stanford.edu/reports/MULTIPLE CHOICE CREDO.pdf

[30] Mead, S. (2006) Maintenance Required in Michigan. Education Sector Reports: Charter Schools. Charter Schooling Series. http://www.educationsector.org/sites/default/files/publications/Michigan_Charter_Schools.pdf

[31] Center for Research on Educational Outcomes (CREDO) (2013) Charter School Performance in Michigan. http://credo.stanford.edu/research-reports.html

[32] Great Schools (2013) Great Schools. http://www.greatschools.org/michigan/

[33] Wayne RESA (2012) 2011-2012 Wayne County School Directory. IBM SPSS Statistics, Version 21, Wayne, Armonk.

[34] Newton, R. and Rudestam, K. (1999) Your Statistical Consultant. Sage, Thousand Oaks.

[35] National Center for Educational Statistics (NCES) (2006) A Closer Look at Charter Schools Using Hierarchical Linear Modeling. National Assessment of Educational Progress. http://nces.ed.gov/nationsreportcard/pdf/studies/2006460.pdf

[36] Shulman, L.S. (1987) Knowledge and Teaching: Foundations of the New Reform. Harvard Educational Review, 57, $1-21$.

[37] Merseth, K.C., Cooper, K., Roberts, J., Tieken, M.C., Valant, J. and Wynne, C. (2010) Inside Urban Charter Schools: Promising Practices and Strategies in Five High-Performing Schools. Harvard Education Press, Cambridge.

[38] Bangser, G., Burgess, C., Chalhoub, T., Cohen, E., DiSalvo, K., Haugen, D. and Henderson, H. (2012) Urban Education That Works: Moving Past School Type Debates and Embracing Choice. Princeton University-The Woodrow Wilson School of Public and International Affairs, Princeton. 